\title{
INFLUENCE OF EXERCISES ON THE FINAL RESULT IN THE E-LEARNING ENVIRONMENT
}

\author{
Nevzudin Buzađija, MSc \\ Mješovita srednja tehnička škola, Travnik \\ (Bosnia and Herzegovina) \\ e-mail: nevzudinb@bih.net.ba
}

\begin{abstract}
S u m m ary
In this work, through the research which was organized in one high school in Bosnia and Herzegovina, the influence of exercises on the final result in the elearning environment at the final test done by students will be shown. The research was conducted in the subject of informatics in years I, II and III. The questions included multiple choice, open-end and matching questions. The aim was to see how much influence these online exercises had on the final outcome. This was demonstrated through the final informatics tests taken by students in a classical way in the classroom, after the completion of teaching of the subject matter planned according to high school rules. In the research, care was taken to provide the conditions necessary to conduct the experiment with regard to technical requirements allowing students access to the blended system of teaching. Recent experience has shown that the young like to use IT and communication devices. In order to secure the necessary conditions, a survey was conducted among the students about meeting the technical preconditions of access to online testing and about students' knowledge of work with the Claroline LMS platform. The aim was to increase motivation of high school students with regard to the use of online materials, because in high schools of Bosnia and Herzegovina almost nothing is being undertaken concerning the implementation of new information and communication technology.
\end{abstract}

Key words: Bosnia and Herzegovina, blended learning, Claroline, elearning, exercises, motivation and web technology

\section{Introduction}

The teaching of informatics involves the use of computers for the practical realisation of the curriculum. This, however, depends on the schools being provided with informatics cabinets. The curricula are obsolete and don't follow changes that happen in achievements regarding information and communication technologies. Because of the current situation, there is no unique educational system and patchworking prevails, as teachers are left to themselves to create the teaching process at their discretion. 
The work's goal is to find and prove the needs for implementation of new achievements in mastering and acquiring knowledge by students in the teaching of informatics, especially by those who are below the average level. The article deals with students who face difficulties in following the teaching process, but also with those who want to learn more. Today, it is necessary to develop a students' awareness of the need for continued practicing for the purpose of achieving results that are necessary in order to prepare students for the use of the acquired knowledge after finishing school. For this purpose, different methods are used in order to motivate students.

According to the students', there is not enough interest to learn something new and achieve exceptional results which would help them in creating their ways of living, especially concerning recent knowledge in informatics.

Because of that, we want to explore in this work how and in what way the exercises created in the Claroline LMS platform influence the final outcome concerning the results which students show at the final test. The aim is to show in which way we can affect students' motivation, and at the same time make students accept it. In this work, we will show how much online exercises influence the results that students obtain in order to approach this issue in a systematic way.

\section{Overview of previous researches}

Many researchers have different opinions of the role of e-learning in educational process from the standpoint of influencing the possibilities to increasing pupils' and students' motivation as well as concerning the influence on the results of acquisition of the subject matter.

An effective e-learning evaluation allows us to define what kind of future we may expect concerning the implementation of this educational system as a new value of the existing educational system in high schools. E-learning efficiency cannot be taken for granted as it depends on multiple factors, primarily on the manner of approach to the creation of educational content in a multidiscipline way. While creating the course adapted to this age, it is also necessary to take care about pedagogical-methodical approaches in their creation in order to satisfy the social aspect of teaching.

E-learning efficacy demands specific conditions, constant following and much more researching, in order to find and develop an acceptable and proved universal model for its evaluation.

The development and use of e-learning represent an individual, organizational and social approach. Because of that, e-learning efficiency should be evaluated. By knowing the e-learning efficiency, we can learn the value of its usage. The measurement of efficiency can represent a useful tool in making decisions about the use of the e-learning strategy. [Figueira, 2003].

In fact, the main factor for e-learning efficiency is acceptance of this kind of education by students, which would be integrated into the existing system. It must 
also be accepted by the teaching staff. Unfortunately, they have been showing an even greater resistance than the students who have not been informed about the advantage and importance of it.

That is why students must perceive the advantage of online teaching and exercises for a better acquisition of the subject matter. That problem was also researched by [Bonk, 2002] who recognizes the problem of inadequate motivation for online teaching of some students. [Kurse, 2004] states that "without students' desire for studying, the process of integration and transformation of e-learning is getting slower. Many students in a corporate environment, who are forced to finish a training program, are motivated just enough to pass the test".

The overview of the existing literature which explores the efficiency of elearning is divided. For example, [Johnson et al., 2000] and [Piccoli et al., 2001] state that there are no significant differences in learning between those who use the classical way of education and those who use the ICT support. On the other hand, some researchers such as Andrewartha and Wilmot [Andrewartha and Wilmot, 2001] and Ladyshewsky [Ladyshewsky, 2004] talk about significant improvements in studying and motivation of students who use e-learning.

The context of e-learning quality depends on how well an environment for studying is prepared. Holsapple et al. point to the importance of the content and elearning environment [Holsapple et al., 2008]. Furthermore, effective management, i.e. a timely introduction of students to all the changes and the criteria for evaluation defined in advance, allows students to feel more comfortable and facilitates greater students' efficiency in e-learning.

Blended learning goes beyond the time's barriers, locations and cultures, and has created much better possibilities for students and teachers. Today, because of blended learning advantages such as increased efficiency, promotion of teacher student interaction, online access and feedback possibilities through physical contact, etc., this way of teaching suits many teachers and education institutions, and the implementation of blended learning is growing fast almost everywhere in the world [Gómez, J. \& Igado, M., 2008].

\section{Sample}

The research comprised students of electrical engineering, profession: electrical technician in computer techniques and automatics - years I, II and III. The classes were of mixed gender structure, namely - 34 girls and 60 boys. Students were also of different residential background, namely - 32 students from the urban area and 62 students from the countryside. 
Table 1: 'Number of students classified by classes

\begin{tabular}{|c|c|}
\hline Classes & Student number \\
\hline $\mathrm{I}_{3}$ & 29 \\
\hline $\mathrm{II}_{3}$ & 31 \\
\hline $\mathrm{III}_{3}$ & 34 \\
\hline Total & 94 \\
\hline
\end{tabular}

Exercises that were additionally provided to the experimental group were created in the Claroline administrative frontend and were in the form of multiplechoice, open-end and matching questions. These exercises are the independent variable because they were not taken into consideration during evaluation, but they had the role of improvement and increase of students' motivation.

\section{Methodology}

Before the experiment, we conducted an anonymous survey via a questionnaire used to obtain information in the experimental group about: possession of preconditions for e-learning usage, reasons for using a computer, opinions about the subject (informatics) and desires concerning the enhancement of results expected from the subject.

Also, we were interested to learn whether using computers and the Internet can improve the level of students' knowledge and increase their motivation towards the acquisition of informatics material through a synchronized approach and through communication with the teacher by email.

After conducting the survey, we introduced students with e-learning terms and what it offers them, and with the way of accessing the material of the Claroline system, the way of testing and knowledge evaluation and other elements which this system contains. As most of students of this group didn't have an email address, which is necessary for teacher-student communication and for better communicating and informing, they were instructed to create their personal email accounts. After that, we approached the users' registration in the Claroline system to prevent other students to register in order to achieve better following and conducting of the experiment. Every student received specific instructions in written form, username and password. Before the beginning of the experiment, students could access the system for practice. This was necessary, especially for students of the first year, who did not have enough previous knowledge, in order to eliminate all possible problems during the testing.

At the students' recommendation, we also created themes within the forum which students could use in the Claroline system and communicate on the posted topic.

After the completion of the experiment, we conducted a survey questionnaire among students from the experimental groups in order to learn about the level of 
understanding of the subject matter with the help of computers and ITS. We wanted to gain knowledge about the effects of certain employed system components (regarding clarity of questions in the Claroline platform), about "stage fright" and its impact through positive or negative experience, and about satisfaction and results of studying in given conditions.

In this way we wanted to evaluate the effect of this manner of teaching on the enhancement of students' motivation for studying. We stated earlier that a very small students' motivation for learning subject matter is present nowadays in schools.

During this research, the results obtained from questioning about e-learning effects on students' success and motivation were used. With this research, we wanted to check the extent of the influence that the exercises conducted in e-learning frontend can have on the results which students obtain at the final test.

Students accessed exercises contained in online tests after the teaching of units in classroom was finished. Questions were formed to cover the material taught by teachers up to this time. Questions were varied by type and content, and there were multiple-choice, open-end and matching questions.

During the questioning that lasted for two months, students had three exercises. The students had to access e-learning exercises when they had completed one teaching unit. At the end, the students took the final test in the classroom in the traditional way.

Software Statistic 8 was used during the processing of results.

\section{Student's attitudes}

The important question is whether students' interest, motivation and readiness to learn and discover something new can be increased with the use of ICT. In the survey we conducted on 94 students, we asked: "If you had a choice, what type of learning would you chose?" We gave three possible answers to this question:

- Traditional,

- E-learning,

- Combination of traditional education and e-learning.

The result of the survey showed that 73 examinees (77.6\%) accepted the answer - combination of traditional and e-learning. These results show that students are interested in changes and would accept this kind of education. It is encouraging that interest does exist, and especially that it is the biggest for that kind of education which is currently gaining prominence in the world. The result is even better when we know that this kind of education is still at its initial stage in high school education. This term is related to the combination of traditional education and elearning, which includes the best elements of both types of education.

After the end of the research, the results of the survey showed that $79 \%$ of students completely understood the content they had processed in the Claroline system environment, $14 \%$ of them understood partially and $6 \%$ of them didn't 
understand the content. Even though the majority of them understood the teaching material, this shows that there are also those who understood the material partially or did not understand it al all, and that students should be better trained in order to use this kind of studying without problems.

The aim of the survey's question: "Can you compare the informatics teaching in the blended system with classical teaching?" was to learn students' attitude towards the blended system. The result of the survey's question showed that $80 \%$ of students considered the informatics matter to be more interesting when used in an elearning system and the majority of students wanted to continue with this kind of education. $74 \%$ of them wanted e-learning to be applied continuously, while only $15 \%$ of them wanted this occasionally.

Also, it must be taken into consideration that students and teachers from our country mostly have not had any experience with e-learning, but still they recognize its advantages. Resistance to changes even for this kind of education is still present in our country because of not being aware of the world's trends and because of the opinion that e-learning does not have the same status as traditional education.

The attitudes obtained from the students justify the research of the teaching methods and confirm the direction in which blended education system in high schools of Bosnia and Herzegovina should be developed. On the other hand, it is necessary to define the individual effects of some elements, contained in the LMS platform, on the students' results - in this case, the influence of the exercises on the students' results in classical tests.

\section{Research types}

The research was classified as a development research as it dealt with concrete problems of gaining knowledge in informatics and the effect of e-learning exercises on students' results at the final test. Namely, in Bosnia and Herzegovina, no cases had been examined which would show the influence of exercises and how they can affect students' motivation.

On the sample included in this experiment, on the basis of indicators and statistics recorded by the LMS system (N.B.: Claroline free software was used), the skill and speed of education program acquisition created in the system with the help of e-learning devices were explored.

The Claroline authors opted for a dynamical learning model, according to which they created and developed the LMS and chose a simplified learning model with five components, as shown in the picture below: 


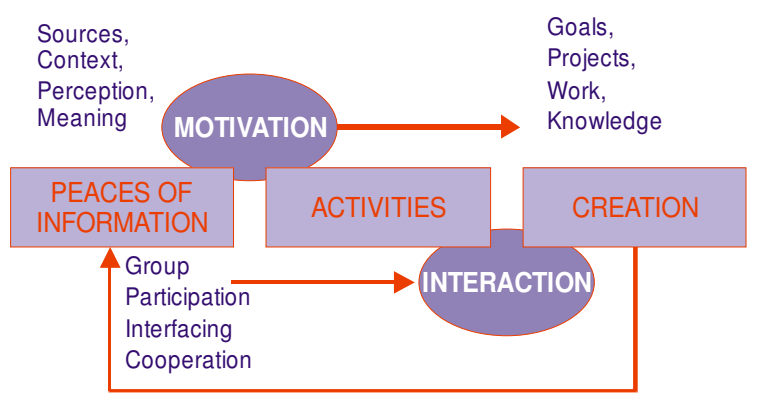

Picture 31: Claroline pedagogical model [Lebrun M., http://www.claroline.net/e_learning_with_claroline.htm]

LMS (Learning Management System) is a set of standardized learning components, which are defined to connect studying with the existing informatics systems inside an organization or via a learning web portal. Its aim is to establish a centralized learning environment via computers within an institution, class or group over a short period of time. The software that makes the basics of LMS manages all elements of teaching and records all parameters required for process monitoring [Ellis, Ryann K., 2009].

\section{Results and discussions}

The aim of the results shown below was to define the exercises and their influence on the students' result in the final test. The canonical-correlation and regression analyses were used to research the influence.

These results primarily need to show in what way we can integrate e-learning with the classical way of education. According to the conducted surveys at the end of the research, it is noticeable that students were pleased with the way of communication among participants of this process and that this way suited them to revise the material. Also, it is noticeable that students understand questions in the context of answering, which makes them more interesting. After the completion of testing in e-learning frontend, students pointed out the importance of exchange of specific opinions in relation to possible answers to the posted questions and the possibility of gaining additional knowledge about problems treated by these questions. Students were prevented from too often using the forums created on the LMS platform as well as chat in mutual communication and communication with their teacher. Another advantage is that they obtained and could have insight in the results achieved in online exercises immediately.

The students were faced with difficulties in constructing online exercises when the telecommunication network was overloaded and when the time they had at their disposal to answer the posted questions was too short. Such time barrier was set to prevent manipulation and abuse in creating online exercises. It thus happened that they did not have enough time for thinking. Another problem occurred 
concerning the acquisition of knowledge gained in this way, as practical ways of dealing with a problem, which can occur in real practice, were not available to them.

The students' results of the exercises are shown under the labels V1, V2 and V3, while the students' results at the final test are shown under the label ZT. The final test examined the informatics subject matter which was covered previously and which was practiced throughout e-learning exercises. The subject matter comprised all classes, and it was planned to be covered during that period according to the Informatics curriculum.

The results achieved in grades II and III will be shown in this research.

In the second grade (Table 1) only one latent dimension was isolated, which explains the overall effect on the result of the final test with $90.18 \%$.

The structure of isolated canonical factors of exercises and final test is given in the table of canonical factors structure (Table 2). Considering the structure of the isolated canonical factor, it can be seen that the results of the exercises achieved in V3-2, i.e. exercises that preceded the final test, had the biggest influence.

Table 1 Characteristic roots and explained parts of collective variance

\begin{tabular}{|c|c|c|c|c|}
\hline & Eigenvalue & $\begin{array}{c}\% \text { Total } \\
\text { - variance } \\
\end{array}$ & $\begin{array}{l}\text { Cumulative } \\
\text { - Eigenvalue } \\
\end{array}$ & $\begin{array}{c}\text { Cumulative } \\
-\% \\
\end{array}$ \\
\hline 1 & 3.607222 & 90.18055 & 3.607222 & 90.1806 \\
\hline 2 & 0.212101 & 5.30252 & 3.819323 & 95.4831 \\
\hline 3 & 0.109776 & 2.74440 & 3.929099 & 98.2275 \\
\hline 4 & 0.070901 & 1.77253 & 4.000000 & 100.0000 \\
\hline
\end{tabular}

Table 2 Canonical factors structure

\begin{tabular}{|c|r|}
\hline & \multicolumn{1}{|c|}{ F1 } \\
\hline \hline V1-2 & -0.955000 \\
\hline \hline V2-2 & -0.915003 \\
\hline \hline V3-2 & -0.962820 \\
\hline \hline ZT-2 & -0.964854 \\
\hline \hline Expl.Var & 3.607222 \\
\hline \hline Prp.Totl & 0.901806 \\
\hline
\end{tabular}

In Table 3, the mutual connection of students' results achieved in certain exercises and the results achieved on the final test can be checked. It is also noticeable that there is a correlation between results of single exercises as the research dealt with the matter which was mutually connected, and it couldn't just be observed as unique thematic unit concerning the matter covered for this informatics class. 
Correlations are more than usual, probably because examinees were aware of belonging to the experimental group and because intelligence development cannot be affected. That is why the real variability and collective co-variability were spread over all tests. This fact gives us stronger security in the interpretation of correlations between intelligence and knowledge.

Table 3 Matrix of variables inter-correlations

\begin{tabular}{|l|l|l|l|l||}
\hline & $1-2$ & $2-2$ & $3-2$ & $\mathrm{~T}-2$ \\
\hline \hline & & & & \\
$1-2$ & .00 & & & \\
\hline \hline & & & & \\
$2-2$ & .82 & .00 & & \\
\hline \hline & & & & \\
$3-2$ & .90 & .83 & .00 & \\
\hline \hline & & & & \\
$\mathrm{T}-2$ & .90 & .83 & .93 & .00 \\
\hline \hline
\end{tabular}

The value of the canonical correlation coefficient given in Table 4 is 0.891 , Chi-square $=61.088$ with three levels of freedom; $p=0.000$ is statistically significant. It means that there is statistically significant connection between exercises and the final test.

Canonical correlation analysis was applied for the purpose of establishing maximum connections, i.e. relations between two observed data groups. With the use of Bartlet Lambd's test and its testing with suitable h'-square test, it was confirmed that the results achieved at some exercises were connected to a certain extent with the results achieved in the final test by means of one pair of canonical factors at the statistically significant level $p=0.00$. The connection between the first pair of canonical factors is very large, which is confirmed by the size of canonical correlation coefficient $\mathrm{R}=0.944$ and the explained part of collective variance equal to $89.1 \%$.

Table 4 Isolated canonical function

\begin{tabular}{|c|c|c|c||c|c||}
\hline \hline & $\begin{array}{c}\text { Canonical } \\
-\mathrm{R}\end{array}$ & $\begin{array}{c}\text { Canonical } \\
\text { - R-sqr. }\end{array}$ & Chi-sqr. & $\mathrm{df}$ & $\mathrm{p}$ \\
\hline \hline 0 & 0.944215 & 0.891542 & 61.08829 & 3 & 0.000000 \\
\hline
\end{tabular}

Based on the regression coefficients of BETA and its value Q (BETA), it can be concluded that those exercises which precede the testing will have the greatest influence on the final result, in this case (V2-3). However, the first exercise V2-1 
also has a statistically significant influence. Partial standardized regression coefficient for predictor variable of the first exercise is beta $=0.326, t=2.154$ with $\mathrm{p}=0.04$, while for the third exercise is beta $=0.552, \mathrm{t}=3.612$ with $\mathrm{p}=0.00$.

Data show that the biggest partial effect on the results of the final test was given by the results of exercises which preceded the test, while the second exercise had the smallest effect because questions in the test were multiple choices only, which explains this decreased effect.

Based on the values of non-standardized coefficients of regression, the regression equation can be formed in this way:

$$
\mathrm{ZT}-3=-16.22+0.379 * \mathrm{~V} 1-2+0.152 * \mathrm{~V} 2-2+0.832 * \mathrm{~V} 3-2
$$
calculated.

Based on this equation, the overall expected results at the final test can be

Table 5 Regression analysis

\begin{tabular}{|c||c||c||r||r||r||r||}
\hline & Beta & $\begin{array}{c}\text { Std.Err. } \\
\text { - of Beta }\end{array}$ & \multicolumn{1}{c|}{$\mathrm{B}$} & $\begin{array}{l}\text { Std.Err. } \\
\text { - of B }\end{array}$ & \multicolumn{1}{|c|}{$\mathrm{t}$} & $\mathrm{p}$-level \\
\hline Intercept & & & -16.2233 & 5.880102 & -2.75902 & 0.010281 \\
\hline \hline V1-2 & 0.325517 & 0.151107 & 0.3795 & 0.176170 & 2.15421 & 0.040310 \\
\hline \hline V2-2 & 0.101868 & 0.120161 & 0.1518 & 0.179059 & 0.84776 & 0.404023 \\
\hline \hline V3-2 & 0.552301 & 0.152922 & 0.8323 & 0.230439 & 3.61166 & 0.001224 \\
\hline
\end{tabular}

In grade III (Table 6), it can be seen that only one latent dimension was isolated. The latent dimension explains the overall effect on the results of the final test with $73.8 \%$. The structure of isolated canonical factors of the exercises and final test is given. Considering the structure of isolated canonical factors, it is noticeable that the results of the exercises achieved on V3-3, i.e. the exercises which preceded the final testing had the biggest effect.

Table 6 Characteristic roots and elaborated parts of collective variance

\begin{tabular}{|r|r|r||r|r|}
\hline \hline & Eigenvalue & $\begin{array}{l}\text { \% Total } \\
\text { - variance }\end{array}$ & $\begin{array}{c}\text { Cumulative } \\
\text { - Eigenvalue }\end{array}$ & $\begin{array}{c}\text { Cumulative } \\
-\%\end{array}$ \\
\hline \hline 1 & 2.953012 & 73.82531 & 2.953012 & 73.8253 \\
\hline \hline 2 & 0.549684 & 13.74210 & 3.502696 & 87.5674 \\
\hline \hline 3 & 0.353814 & 8.84535 & 3.856510 & 96.4128 \\
\hline \hline 4 & 0.143490 & 3.58724 & 4.000000 & 100.0000 \\
\hline
\end{tabular}


Table 7 Structure of canonical factor

\begin{tabular}{|c|r|}
\hline \hline & \multicolumn{1}{c|}{ F1 } \\
\hline \hline V1-3 & -0.753953 \\
\hline \hline V2-3 & -0.833197 \\
\hline \hline V3-3 & -0.929705 \\
\hline \hline ZT-3 & -0.908845 \\
\hline \hline Expl.Var & 2.953012 \\
\hline \hline Prp.Totl & 0.738253 \\
\hline
\end{tabular}

In the table of matrixes of variables inter-correlations, the correlation between exercises and the final test can be noticed. This is similar to grade II, although there is smaller intensity of correlation among results achieved during some exercises. This can be explained by the fact that in this class students study $\mathrm{C}++$ language and the subject matter deals with repeating orders which have their specificities. This correlation relationship tells us also about mutual similarities which control some of the repeating orders.

Table 8 Matrix of variables inter-correlations

\begin{tabular}{|l|l|l|l|l|}
\hline & V1-3 & V2-3 & V3-3 & ZT-3 \\
\hline \hline V1-3 & 1.00 & & & \\
\hline V2-3 & 0.48 & 1.00 & & \\
\hline \hline V3-3 & 0.58 & 0.73 & 1.00 & \\
\hline ZT-3 & 0.59 & 0.65 & 0.85 & 1.00 \\
\hline
\end{tabular}

The value of canonical correlation coefficients is 0.733 , Chi-square $=40.343$ with three levels of freedom, $p=0.000$ is statistically important. It means that there is significant correlation between exercises and the final test.

Canonical correlation of analysis was applied for the purpose of defining maximum connectivity, i.e. relations between two monitored data groups. By applying Bartlet Lambd's test and its testing with the help of a suitable h' - square test, it can be declared that there is, to a certain extent, the connection between the results achieved during exercises and the results of the final test with one pair of canonical factors at a statistically significant level of $p=0.00$. The connectivity between the first pair of canonical factors is very high, which is confirmed by the size of canonical correlation coefficient $\mathrm{R}=0.86$ and the elaborated part of the collective variance of $73 \%$. 
Table 9 Isolated canonical function

\begin{tabular}{|c|c|c|c|c|c||}
\hline \hline & $\begin{array}{c}\text { Canonical } \\
-\mathrm{R}\end{array}$ & $\begin{array}{c}\text { Canonical - } \\
\text { R-sqr. }\end{array}$ & Chi-sqr. & df & $\mathrm{p}$ \\
\hline \hline 0 & 0.856498 & 0.733589 & 40.34282 & 3 & 0.000000 \\
\hline
\end{tabular}

Based on regression coefficients of BETA and its importance Q (BETA), it can be concluded that exercises which precede the testing will have the biggest influence on the final outcome, in this case (V3-3). Partial standardized regression coefficient for predictor variable of the first exercise is beta $=0.722, \mathrm{t}=4.844$ with $\mathrm{p}=0.00$.

The data show that the results of exercises which preceded the test had the biggest partial influence on the final test results. On the other hand, the second group of exercises had the smallest influence questions in the test were multiple choices only, which explains this decreased effect.

Based on the values of non-standardized coefficients of regression, the regression equation can be formed in this way:

$$
\mathrm{ZT}-3=-24.33+0.201 \mathrm{~V} 1-3+0.132 \mathrm{~V} 2-3+1.216 \mathrm{~V} 3-3
$$

Based on this equation, the overall expected results at the final test can be calculated.

Table 10 Regression analysis

\begin{tabular}{||c|c|c|c|c|c|c|}
\hline \hline & Beta & $\begin{array}{c}\text { Std.Err. } \\
\text {-of Beta }\end{array}$ & B & $\begin{array}{l}\text { Std.Err. } \\
\text { - of B }\end{array}$ & $\mathrm{t}(30)$ & $\mathrm{p}$-level \\
\hline Intercept & & & -24.3309 & 10.61937 & -2.29118 & 0.029150 \\
\hline \hline V1-3 & 0.131781 & 0.116654 & 0.2013 & 0.17821 & 1.12967 & 0.267565 \\
\hline \hline V2-3 & 0.067650 & 0.137465 & 0.1319 & 0.26802 & 0.49213 & 0.626212 \\
\hline \hline V3-3 & 0.721873 & 0.149032 & 1.2159 & 0.25103 & 4.84375 & 0.000036 \\
\hline
\end{tabular}

From the results shown in this research, we can notice the influence of the predictor variables (exercises) on the criteria variable (the results achieved on the final test), with this influence being more expressed in grade II. This research had multidimensional access towards checking the reliability of the data obtained during the research. Naturally, this initial research is not fully reliable due to a small number of results and a short period of time. In order to obtain statistically reliable results, this research has to be followed over a longer time period and on a bigger sample.

However, it is without a doubt that the influence exists, but we can't define precisely how big the real influence is. The results of the surveyed population have shown that improvement is noticeable, not only through achieved results at the final 
test, but also the evident influence on the improvement related to students' motivation for discovering something new.

\section{Conclusion}

This research is in the context of the integration of contemporary discoveries and the ICT and Internet usage in the classical education system. The blended learning system is only possible in high schools, not only because of the legal barriers but also because of the social and pedagogical factors. Namely, in this kind of teaching, we don't lose the social and pedagogical principle because students still socialize and exchange their opinions. On the other hand, they have direct contact with teachers through classical education and in this way we obtain high quality factors which must be met with regard to the students' age, concerning both educational teaching and upbringing.

With this kind of approach to the students, pleasure was noticeable throughout the survey. Less time was needed in order for the students to accept online teaching in comparison to teachers, who had a negative attitude towards it. This can be explained by the situation in Bosnia and Herzegovina where teachers don't have suitable informatics literacy and, due to that, show resistance to the blended learning system.

The increased influence of online exercises on the final test results is noticeable as the statistically significant influence can be noticed in grades II and III. It is also noticeable in canonical-correlation and regression analysis which tested the achieved results. In both cases, the results are matching, which confirms the reliability of the results obtained after the treatment of exercises and final test of this population.

This research shows the universal solution for defining the influence of online exercises on the final test results which students achieve at the final test done in classical way. Qualitative changes were observed after adequately conducted exercises which took into account all aspects presented in expert research concerning their creation.

This research shows statistically significant influence of exercises on the final test results. It could be useful for a future research in this sector to be conducted over a longer period of time. Even the institutions which deal with creation of education strategies can benefit from it in order to strategically approach to the planning of the introduction of online exercises in all subjects. However, despite all the inaccuracies we mentioned, the survey confirms that students find interest in this kind of testing, and an increased students' motivation is noticeable. Therefore, competent institutions should initiate the integration of this type of education due to students' results and the increase of informatics literacy of students and institutions' personnel. 


\section{Bibliography}

1. Andrewartha, G. and S. Wilmot (2001): Can multimedia meet tertiary educational needs better than the conventional lecture? A case study, î Australian Journal of Educational Technology (17:1), 2001, pp. 1-20.

2. Bonk, C. (2002): Research related to the effectiveness of e-learning and collaborative tools. http://www.trainingshare.com/download/australia/TAFE_sydney/tools.ppt

3. Figueira, E. (2003): Evaluating the effectiveness of e-Learning strategies for SMEs. http://www.theknownet.com/ict_smes_seminars/papers/Figueira.html

4. Johnson, S. D., S. R. Aragon, and N. Shaik (2000): Comparative Analysis of Learner Satisfaction and Learning Outcomes in Online and Face-to-Face Learning Environment, î Journal of Interactive Learning Research (11:1), 2000, pp. 29-49.

5. Gómez, J. \& Igado, M. (2008): blended learning: the key to success in a training company. International Journal of Instructional Technology and Distance Learning, 5(8).

6. Graham, C. R. (2005). "Blended learning systems: Definition, current trends, and future directions.". in Bonk, C. J.; Graham, C. R.. Handbook of blended learning: Global perspectives, local designs. San Francisco, CA: Pfeiffer. pp. 3-21.

7. Holsapple, C. W. and Lee-Post, A. (2006): "Defining, Assessing, and Promoting ELearning Success: An Information Systems Perspective." Decision Sciences Journal of Innovative Education, 2006, Issue 1, Vol. 4, pp. 67-85

8. Kurse, K. (2004): The magic of learner motivation: The ARCS model. http://www.elearningguru.com/articles/art3_5.htm

9. Ladyshewsky R. K. (2004): E-learning compared with face to face: Differences in the academic achievement of postgraduate business students, Australasian Journal of Educational Technology, (20:3), 2004, 316-336.

10. Leung, T. Y., and Tran, S. Y. S. (2000): Integrating the Strengths of the Web-Based and Traditional Models of Teaching.. Paper presented at the International Vocational Education and Training Association conference, Hong Kong, China, August 6-9,. (ED 446 247)

11. Piccoli, G.., R. Ahmad, and B. Ives (2001): Web-based virtual learning environments: A research framework and preliminary assessment of effectiveness in basic IT skills training, MIS Quarterly (25:4), 2001, pp. 401-426.

12. Shee, D. Y. and Wang, Y. S. (2008): "Multi-criteria evaluation of the web-based elearning system: A methodology based on learner satisfaction and its applications." Computers \& Education, 2008, Issue 3, Vol. 50, pp. 894-905.

13. Stankov, S., Grubišić, A., Žitko B. (2004): E-learning paradigm \& Intelligent tutoring systems. In: Kniewald, Z. (ed.): Annual 2004 of the Croatian Academy of Engineering. Croatian Academy of Engineering, Zagreb. 
Metodički obzori 7(2012)2

Izvorni znanstveni rad

UDK: 371.6:004]:373.5](497.6)

Primljeno: 20. 1. 2011.

\title{
UTICAJ VJEŽBI NA KONAČAN REZULTAT U OKRUŽENJU E-LEARNINGA
}

\author{
Mr. sc. Nevzudin Buzađija \\ Mješovita srednja tehnička škola Travnik \\ (Bosna I hercegovina) \\ e-mail: nevzudinb@bih.net.ba
}

\section{Sažetak}

U ovom radu kroz istraživanje koje je orgnizirano u jednoj srednjoj školi $\mathrm{BiH}$, bit će pikazan uticaj vježbi u okruženju e-learninga na konačan rezultat na zavrnom testu od strane učenika. Istraživanje je provedeno iz predmeta Informatika u I, II i III razredu. Pitanja su bila tipa višestrukog izvora, dopune i pridruživanja. Cilj je da se vidi koliko ove on-line vježbe imaju uticaja na konačan ishod koji se ogleda kroz završni test iz Informatike od strane učenika i koji se radi na klasičan način u učionici nakon pređenog gradiva planiranog po propisima srednje škole. U istraživanju se vodilo računa da se obezbjede svi preduslovi za nesmetano sprovođenje ekspermenta u pogledu tehničkog obezbjeđenja preduslova za pristup učenika kombiniranom načinu podučavanja. Iz dosadašnjeg iskustva primjećuje se da mladi vole korištenje IT i komunikacijskih uređaja. Kako bi se obezbjedili svi neophodni uslovi provedena je anketa među učenicima o posjedovanju tehničkih preduslova pristupa on-line testiranju i o poznavanju principa rada od strane učenika u LMS platformi Claroline. Cilj je da se pveća motiviranost učenika srednjih škola u pogledu korištenja on-line materijala jer u $\mathrm{BiH}$ u srednjim školama gotovo da se ništa ne poduzima po pitanju uvođenja novih mogućnosti IKT.

Ključne riječi: Bosna i Hercegovina, kombinirano učenje, Claroline, eučenje, vježbe, motivacija, web tehnologija 